\title{
Transmedia Festivals and the Accelerated Cultural Sector
}

\author{
Bianca Ludewig \\ University of Vienna \\ bianca.ludewig@wiseup.de
}

\begin{abstract}
Over the past couple of decades, urban transmedia festivals have gained a distinct presence in the European cultural landscape, constituting an alternative to other, more dominant, conceptions of music festivals. This article introduces transmedia festivals as a new type of contemporary festival and situates them in wider urban processes. Transmedia festivals originated on the fringes of new urban scenes, in which media art overlapped with electronic music and club culture. Based on multi-year field research, this article argues that these festivals have become part of urban renewal processes. The core focus of this article is therefore how transmedia festivals are part of processes such as eventization, culturalization, precarization, and gentrification. Local and EU-funding-policies, moreover, impose opportunities and dilemmas on urban festivals. The article is a contribution to the still small area of cultural and urban studies on such festivals in Europe, and situates transmedia festivals within urban cultural change.
\end{abstract}

Keywords: Avant-garde, Transmedia Festivals, Eventization, Urban Transformation, Precarity, DIY.

\section{Introduction}

This article explores connections between transmedia festivals, the city, cultural politics, and policies. The article draws from longitudinal ethnographic research, but has a conceptual focus. It outlines core themes and perspectives generated from fieldwork and maps these issues in literatures across a range of disciplines such as urban cultural theory, philosophy, anthropology, sociology, and art history.

My field research focused on the CTM Festival in Berlin, Germany at which I first completed an internship followed by volunteering. Until today, I have been involved in different forms within the festival, including participation in various side events connected to the festival and its networks. Moreover, I attended CTM with students in the context of seminars I was teaching, about festivals and their scenes. These different forms of participation were documented through fieldnotes and photographs. The field research was inspired by conceptions of multi-sited ethnography (cf. Marcus 1995, 2009, 2013). In compliance with the ideas of multi- 
sited research, I followed the networks of the festival - its curators and visitors - to other festivals as it is of importance to compare contexts and practices. I conducted about fifty interviews with festival curators, team members, volunteers, interns, artists, and long-time festival attendees. I did additional follow-up interviews with some of the informants, especially with the curators. As a researcher, I moved back and forth between several places and sets of data (cf. Falzon 2009). I revisited some of the festivals several times, in the form of a Pendulum or YoYo type of fieldwork (cf. Welz 2013; Wulff 2007).

\section{A tentative definition of transmedia festivals}

The starting and focus point of my research was the CTM Festival, but my theorization also draws from fieldwork at the following festivals:

Heart of Noise (Innsbruck, AT)

Elevate (Graz, AT)

Ars Electronica (Linz, AT)

Hyperreality/Wiener Festwochen (Vienna, AT)

Unsafe and Sounds (Vienna, AT)

Rokolective (Bucharest, $\mathrm{RO}$ )

UH Fest (Budapest, HU)

Next Festival (Bratislava, SK)

Atonal (Berlin, DE)

3hd Festival (Berlin, DE)

Cynetart (Dresden, DE)

Chaos Communication Congress, C3 (Leipzig, DE) (1)

Transmedia festivals have proliferated since the turn of the century and are increasingly established across Europe. There are at least forty transmedia festivals in Europe. Transmedia festivals can be defined as a distinct type of arts festival that combines media art, music, and technology. Some of the journalists and experts who advise or co-curate these festivals call them avant-garde festivals. In the following, I use both terms "avant-garde" and "transmedia" but not synonymously, as both terms underline different aspects of the festivals in question.

The term transmedia emphasizes the aspect of art in connection to technology whereas avant-garde is more of an umbrella term. The avant-garde emphasizes a strong orientation towards the idea of linear progress and is characterized by a particular radicalism towards existing, predominant aesthetic norms. One could also speak of antagonistic, utopian ideas and practices of underground scenes, counter cultures, and alternative movements that are directed against the ruling order. Even though the discovery of new media in itself has historically always been accompanied and promoted by the artistic avant-garde, the aspect of technology is not contained in the avant-garde concept and is not a necessary prerequisite. What speaks against the use of the avant-garde concept, despite its comprehensibility, is the fact that avant-garde can only be marked a posteriori (see Enzensberger 1962). Whether avant-garde is a valid and suitable reference for these festivals will only become clear over time. 
Transmedia festivals are dedicated to electronic and experimental music and a diverse range of artistic practices, as demonstrated by the centrality of the terms transdisciplinarity and intermediality in the discourse of this festival culture. The individual festival creates a symbolic sphere in which exhibitions, films, performances, music, and installations are arranged, presented, staged, and contextualized (Teissl 2013: 12, 44, 59). Transmedia festivals emerged during the time of digitization and are themselves a part and outcome of this process. Curators consider technology vital to their self-conception and program. Transmedia festivals are usually urban events, taking place in big cities or regions' capital cities. Most of them use existing cultural venues like theatres, galleries, clubs, and concert halls for their festival editions. The urban environment is crucial as it connects them to the local scenes and their flows of taste, style, and information "seeing the city and scene as inseparable spatial and social phenomena that define each other (...)" (Stahl 2005: 312, see also Stahl 2014). Transmedia festivals follow the principles of the big art exhibits (world expositions, art biennales) rather than those of the common open air music festival (TeissI 2013: 27-48). Many of the curators I talked to have a background in the arts.

Most curators are interested in the same kind of music, although some festivals focus on specific genres (noise, techno, industrial, post-club, electroacoustic, ambient, or similar styles). In general, though, one can always find recurring artist names, which can be filed under wide ranging umbrella-categories like experimental or electronic music. What changes from festival to festival is the art form which is combined with the music. This can be technology, performance, dance, film, discourse, or fine arts. In the field of fine arts, most festivals present art that is somehow linked to technology. Most common are sound art, media art, and audio-visual art.

My ethnography focused on organizers and long-term attendees involved in the scenes from which such transmedia festivals evolve. The majority of the producers, i.e., the core production team as well as the volunteers, are often former festival visitors who wanted to be more involved. Many simultaneously work as organizers, artists, promoters, or journalists, and are involved with the festival circuit at large. They are often identified as "accredited professionals". I assume that about 30\% of the festival visitors are such associated professionals. Even if they appear to be audiences, their participation involves professional or career interests, such as networking towards future projects. Those without a regular job at those festivals are often Do-lt-Yourself (DIY) activists who contribute to the scene and its networks. Some of them live under precarious economic conditions, although being highly educated and multi-skilled professionals. They push things forward with their activism, but often live off very little money (Ludewig 2018: 126).

\section{Festival economics and cultural politics}

The organization and financing of transmedia festivals are entangled with cultural policies and networks in the urban environment. The environment of production is essential to understanding the outlook of the festivals. Lioudmila Voropai (2017) explains, in her in-depth study on media art institutions, that at the end of the twentieth century, a paradigm shift took place. The legitimation discourse of art institutions changed and a new ideology and social function was put into effect by neoliberalism. This transformed the cultural institutions, which were brought to life by the ideals of the Enlightenment, into profit-driven business corporations. Critical, progressive, and transgressive projects and institutions have adapted themselves to 
these new conditions. Moreover, Voropai suggests that in post-industrial society, the relationship to power shifted further from artists to institutions and distribution, forcing curators and artists to adapt themselves to the system in order to retain or improve their position (ibid.: 20ff). The institutionalization of media art evolved from the economic and political interpretation of the new art form since the 1980s, which was mainly related to the potential of new technologies to generate new markets and investments, and, thus, to facilitate a better future. The understanding that media art offered surplus value compared to other art forms became an accepted discourse in Western Europe (ibid.: 22-23).

New media in art projects was thus seen as creative exploration of these new technologies, going far beyond the boundaries of a purely artistic practice. In the early theoretical essays on media art, Voropai explains that media art was first and foremost seen as the avant-garde of such creative explorations of the new technologies and as an important experimental space which should serve the purpose to render those new technologies more meaningful. In the discourse on media art initiated by cultural and political institutions, a special status for media art was claimed from the outset in that media art was useful for the whole society as an interdisciplinary activity which encompasses art, science, and technology. The idea of media art as a free artistic practice was not on the agendas of mediainstitutions (Voropai 2017: 22-23). Voropai's case studies on the history of mediaartistic institutions confirm the thesis that the expansion of an institutional network for the new artistic forms and practices presumed as (new) media art, was the result of political decisions from above and much less often from below, as a result of artist initiatives and self-organized activities. Many media-artistic festivals, museums, and other institutional foundations were originally initiated by the federal state, city governments, and individual politicians who implemented them (2017: 23).

Today, apparently, (renowned) festivals are functioning as institutions for their scenes and art forms. Voropai, accordingly, examines not only museums and art spaces but also festivals as institutions. Two of her examples are related to my research: the transmediale, which is the sister-festival of CTM (ClubTransMediale), and the Ars Electronica festival. Voropai's analysis suggests that transmedia festivals are an outcome of cultural politics linked to media art, as there were huge investments by cities and states into media art. Festivals, organizations, and museums were founded, and project-funding was remarkably easily available for these artistic practices. As there was a strong overlap since the 1980s across the (small) scenes which were interested in new media art and those experimenting with electronic music, those people met in the 1990s at media art events particularly in Berlin and in the evolving club spaces. The CTM festival in Berlin was originally a supplement to transmediale, which started in 1988 as an independent video art festival. It was born out of a critique, as transmediale did not include music in its media art show and conference. Since 2004, the transmediale is being supported as a top cultural institution by the Federal Cultural Foundation, beside events like Berlin Biennale and documenta (an exhibition of international contemporary art founded in 1955 which takes place every five years in Kassel, Germany).

In 1999, the CTM festival was launched in consultation with transmediale as an accompanying event consisting of artistic and above all musical positions under the title "10 Days at the Interface of Image and Sound" (cf. Interview RohIf 2014, CTM director). Throughout the years CTM became an independent festival of its own, including media art. It can be assumed that festivals like CTM also developed as a 
result of financial constraints. There was, back then, almost no funding available for experimental club music, due to the fact that it was typically classified indiscriminately as pop music. Even though the well-funded days for media art were already over, the discourses were still reverberating within governments and institutions.

Most of the avant-garde festivals at stake are financed from state, city, or regional funding. In some cities, there are special institutions for fostering or supporting musical and cultural events that are not classified as "high culture" and thus have less funding opportunities (for example, in Berlin the Musicboard and in Vienna the SHIFT program). Some of the festivals, such as the Ars Electronica, have fixed funding and can be considered as officially institutionalized. Most festivals though, including larger festivals like CTM, don't have such fixed funding (2). This means that the curators - in most cases this job is done by the curators or directors - have to write many funding applications throughout the year. As a consequence, the team remains in uncertainty as to whether or not the festival will actually happen as planned. The finances at most festivals are pieced together thusly: Some money comes from the city and some money, maybe, from the state, and special foundations may also finance parts of the program, like discourses, exhibitions, or workshops. Embassies might pay for flights, and businesses will become sponsors (drinks, clothes, cars, music software, and the like) and offer their products or outright pay for special events. Another important financial source are EU projects. The bureaucratic effort required by these projects is immense. Festivals rely heavily on the financial possibilities of the European Union. EU projects can only be carried into execution if transnational networks exist, because partners need to be in other EU countries. Thus, overall, funding and networks are strongly linked together, and this causes the establishment of ever more networks. In fact, during my research several new networks were formed as a result of EU funding. For instance, ECAS (European Cities of Advanced Sound, 2011-2015), SHAPE (Sound, Heterogenous Art and Performance in Europe; ongoing, $2^{\text {nd }}$ term), and We Are Europe (ongoing, $2^{\text {nd }}$ term).

For Artemis Vakianis (2012: 155), cooperation is an important strategy for the survival of festivals. Using the example of the Steirischer Herbst (AT), she shows the sphinx-like network of cooperations guarantees the standing of the festival and, likewise, it functions as a safety net, against the backdrop of the cutting down of subventions in the Austrian cultural landscape. A part of Steirischer Herbst is Musikprotokoll, a festival within the festival, focused on classical, academic, and experimental music. Musikprotokoll is also part of the ECAS/ICAS network. Through the international network of cooperation partners, the budget of Steirischer Herbst was tripled. Vakianis emphatically stresses the fact that the EU became a relevant source of revenue for festivals, and that one's own network is crucial for upholding this funding (Vakianis 2012: 155). Those festivals and networks, depending on their size and budget, are always transnational and international, but only very rarely global. Thus, western perspectives and non-western perspectives are most of the time unequally represented.

This is an example on how funding is affecting the showcased artworks and projects at festivals and why most invited artists are still from the "West". Verena Teissl worked for many years as an event organizer on the film festival circuit, as well as a cultural mediator. Since 2010, she has been professor for cultural management and cultural studies in Austria. She published a pivotal study (2013) and additional articles (2012) on the genesis and potential of festivals as an event format. In her study, she explains that there is, generally, a lack of equality in international cultural production, because Eurocentric attitudes are immanent in 
the discourses of cultural production at large (2012: 75). Teissl points out that Western productions and artists make up a large percentage of the line-ups at established cultural festivals. Thus, postcolonialism is still in a stage of infancy at arts or music festivals. This tendency is also true for the transmedia festivals. During my research though, most of the transmedia festivals did increase their diversity. This was due to public criticism, but also due to new diversity-aware funding regulations, for example in Berlin from the Musicboard since 2017 (cf. Hoffmann 2017). Very few festivals have had a gender equal line-up from the moment they were founded (there are exceptions, such as Hyperreality or 3hd festival). Some even continue not to practice much diverse-positive action (such as Atonal or Heart of Noise festival). As such, electronic music festivals in general, with some transmedia festivals being part of them, have a huge problem with diversity (regarding gender cf. female:pressure FACTS survey 2013-2017).

Where there is openness towards a global perspective, finances are often a setback. There are very few funding bodies and institutions for such cooperation outside of the EU. In Germany and Austria, the ministry of foreign affairs is in charge of non-European cultural activities. Their interests only rarely intersect with those of transmedia festivals, as they follow geopolitical aims and not aesthetic conceptions. According to Teissl, there is hardly any funding to support the dialogue of global cultures as a future vision. She concludes that countries like Germany and Austria are reinforcing cultural hegemony. She believes that impulses for globality and equality have to be induced by funding-systems, cultural mediation, and curatorial action (2013: 53 and 2012: 83-84). However, curatorial concepts are always dependent on and bound to funding and financing regularities. Examples during my research have shown that even if the financial means are there, such a global perspective is not always desired (3). To sum up: cooperations and networks do not evolve, solely, due to cosmopolitan ambitions and shared interests regarding art forms or critical attitudes, but also due to economic pressure.

\section{Precarity and networked sociality}

Many of the festival producers and visitors are part of a highly mobile, individuated, and glamorized workforce which seems to characterize today's post-industrial urban life and "networked individualism" (Wellman and Rainie 2012:11-12). The resulting working conditions in the cultural and creative realm are often precarious. This is also true for the transmedia festivals. Due to risky finances, most of the German festivals are relying heavily on working with unpaid volunteers, and this is also becoming more common in Austria. A volunteer usually gets a festival ticket for working several shifts. The number of hours is not calculated according to the official minimum wage, but with five Euros per hour on the average (depending on the festival). A hypothesis for further investigation is that cultural work and volunteering is being feminized and of lesser value because of gender inequalities in society. Volunteerism has historically been part of civic organizations in the cultural sector in Europe but is now being promoted as a career opportunity by festivals that operate in a commercial market, including the Roskilde Festival in Denmark (cf. panel at CTM Festival 2019) and the Burning Man Festival in the US (cf. Chen 2009). Festivals also promote volunteerism as a source of authenticity, evoking DIY and community values that are also linked to the normative trends of participation and interactivity in the arts (Relyea 2013). Interns, moreover, can often be considered unpaid labourers, as they receive as little as $€ 100$ per month for nearfull-time jobs, depending on the festival and country. During my research the 
minimum wage act was established in Germany 2015. For the festivals this was financially challenging, and many of them reacted by giving internships to students who needed the credits for university, or students from abroad, where the law can't be applied.

The significant impact of funding regulations on festivals, projects, and cooperations of all sorts has become crucial, and intimate relationships are more and more commercially exploited as networks. Using one's creative skills and personal networks is a practice that came from club culture and internet start-ups, where hierarchies are low and the risks high. Wittel (2001) calls this "network sociality". The network phenomenon itself is closely linked to the unfolding of digital communication technology.

In my research, most subjects can be considered as highly trained in the use of digital media. They move skilfully and elaborately in this environment, master several profiles and platforms. But this does not guarantee them a proper income or reserves for pensions. Though activity in the internet is relevant, it is not sufficient. To be there and meet in person is still crucial, as confidential feedback is needed. Contacts which function as multipliers and nodes in the network are therefore helpful. To access them you have to meet at exclusive events and festivals in different cities and countries, because these music and art scenes are transnational. Here the "free agents" of a "free art scene" (Freie Szene) meet and are on hold to get connected and, potentially, to be embedded in temporary projects. This demands a high mobility that is not affordable to everybody. Lane Relyea, an art theory scholar and journalist, who has also been director of Art History at the Glassell School of Art in Texas since 2001, published a study on art world discourses and art practices which he links to the context of information-age capitalism. Project, platform, and database are the crucial terms for today's art world according to Relyea (2013: 25-26). He reveals in his book how neo-entrepreneurial mythologies like volunteerism and DIY agency are established and imposed in the art world: "DIY serves as the honorific term for the kind of subject required by the constant just-in-time turmoil of our networked world" (ibid.: 5). This is also true for working at avant-garde festivals. Such festivals, cultural projects, and art events created a new form of work that can be subsumed as affective labour (Hardt 1999), which is fuelled by "the euphemism of a 'creative life'" (Relyea 2013: 11).

Relyea locates the root of this process in the history of DIY and neo-avant-garde since the 1960s, particularly in the DIY micro-networks of 1980s underground culture, of which he was an active part himself. The larger context of these initiatives was dramatically reduced in the 1990s by the crumbling welfare state and a shift in policy away from social and workplace security to individual risk taking, speculation, and entrepreneurialism:

And so it goes to this day. The Art world remains in the habit of attributing to its 'avant-garde' practices the same social critique as that made by artists twenty to thirty years earlier. (...) Thus diverting attention from ruptures between then and now toward a reassuring illusion of historical continuity. Worse, actual present-day social conditions are often simply glossed over (Relyea 2013: 115).

As early as 1966, Lawrence Alloway wrote for the magazine Canadian Art: "We are all looped together in a new and unsettled connectivity. (...) Art today is distributed in a network of communications" (Alloway 1966: 35-36). The numerous micro-networks of the 1980s became part of today's big art exhibits like documenta 
or the art biennals (see Relyea 2013 for a variety of examples). The former DIY free agent is now a heroic figure of neoliberalism.

Releya quotes in this context Lev Manovich (2009): "Culture industries have started to systematically turn every subculture (...) into products. In short, the cultural tactics evolved by people [are] turned into strategies now sold to them" (324; here: 48). Boltanski and Chiapello describe this process, too, in their book The New Spirit of Capitalism (2003), where the artist critique is picked up by economics and management only to be eventually assimilated. According to the authors, ideas were taken from the repertoire of the avant-garde since the 1950s, for example regarding festive events, the idea of work as play, emancipatory discourses, and surrealism (2003: 217). Referring to Boltanski and Chiapello, Relyea explains that social economy was obsolete after the crisis of the 1970s and capitalism got its prestige back by hijacking creativity via "networked relationships that 'democratized' managerial expectations" (2013: 124). Accordingly, DIY has become a neo-entrepreneurial mantra and empty index for Relyea:

No longer about condemning the system, DIY is exemplary of how to endlessly bargain and negotiate with it, how to battle for a modicum of romantic glamor and self-worth within it, a sense of worth measured by the system's values and achieved through its laws and norms (ibid.: 49).

The commodification of the art world is, according to Relyea, exemplified in art's social turn, where the artist as individual got replaced by the artist as network (ibid.: 52). Work is now happening in the modus of information, a redesign that happened largely unnoticed: "As cyberphiles like to say, information wants to be free. Such is the freedom of the new free agent, who is both communicational (...) and also informational, which means weightless and event like (...)" (2013: 122). This more networked marketplace and cultural landscape is adaptable to new marketing strategies, and as Relyea argues, it fosters an emerging "nobrow culture" (ibid.: 196): "Far-flung heterogeneity currently signifies not resistance but privilege" (ibid.). This also affects transmedia festivals, whereas fifteen years ago this music and art was only interesting for a small community and a distinctive, mostly DIY, scene. It now appeals to a much larger audience and, hence, its content is much more attractive to brands and companies, which have the money to set up every festival they want, as Jan Rohlf, CTM festival director, explains:

These companies have also the means to make a completely different kind of marketing. They adopt methods and formats that used to exist mostly outside such corporate settings; this has become massive. Independent media are closing down, but instead there are channels like Electronic Beats, Red Bull Radio, Boiler Room TV. Textual content and artistic projects are financed from Mercedes to Intel and in addition there are all the event formats by these brands. Such as Red Bull Music Academy, Electronic Beats festival or Ableton Loop, music events by Vans, Converse or Zalando. (...) Even without these brands there would probably be a development towards these more hybrid forms of music, which corresponds to a life-worldly experience that we all have, that everything becomes more and more mixed... But through these brands, it is massively accelerated and pushed into the public eye (Interview Rohlf 2018, 44.40-47.33, translation by the author). 


\title{
Cultural gentrification or the accelerated cultural sector
}

The term "cultural gentrification" derives from the research field itself. It started to pop up in the past two years in informal conversations at events connected to the festival circuit and eventually in interviews. Cultural gentrification is a result of the interplay between cultural events and the city, though it is not limited to the urban. This relation of events to the city where they happen has been underexposed and underestimated in past research. In my research, I seek to include these connections, with the city of Berlin as an example. In this section, I want to offer some arguments which illustrate these ties. Following Fabian Holt and Carsten Wergin, these are crucial as:

\begin{abstract}
Popular music is produced and experienced within particular social, economic, and technological arrangements between individuals and organizations in the city. Its meanings change within emergent social groupings and neighbourhood dynamics. More specifically, we contend that to analyse popular music in contemporary cities separately from evolving post-industrial issues of regeneration, gentrification, city marketing, and festivalization would be obsolete (Holt and Wergin 2013: 2).
\end{abstract}

Enis Oktay (2014) elaborates on the links between Berlin and its music scenes, terming Berlin as Europe's nightlife capital. Berlin displays a glamorous picture of work life, according to Oktay, where alienation is disguised through aestheticization, by hordes of creative industries workers. They "mix work with play - flexible working hours, informal work space, low hierarchies - and combine income from such jobs with the dole to adopt a precarious yet celebratory lifestyle, which seems to be in a constant state of partying" (2014: 214). And this is meant as a reproof: "In fact, Berlin is being accused by many of being a free-rider; a capital of 'bobo idlers' and welfare recipients, whose sole contribution to the national economy comes from tourism, leisure and creative industries" (ibid.: 211-212). Oktay experiences Berlin as a haven for privileged migrants and first world cosmopolitans, the globally mobile, and the privileged. He considers these people as a new digital-social-network generation who went to university or art-school and who re-appropriated critical theory and post-structuralism. In his perspective, they utilize critical theory to legitimate the marketing of products, hedonistic excess, and network sociality to ultimately facilitate new trends of urban and cultural gentrification. Berlin scenes perform "institutionalized transgression" (213) which is fuelled by the use of networking platforms such as Facebook, Twitter, Resident Advisor, Instagram, and Restrealitaet (a special platform for clubbing). As a side effect, Berlins' complex and not always glamorous past is deleted or at least forgotten.

In Berlin, partying is often connected to work, but this remains invisible to outsiders, and often also remains unnoticed by those affected. The Institute for Precarious Consciousness (IPC) attempts, in its theorization of precarity, to merge digital technology and the credit system with the neoliberal concepts of success and career. Today, communication through technology is omnipresent and more common than ever before, but only through controlled, monitored, and mediated channels. Zygmunt Bauman describes this moment as "war for recognition where we must represent ourselves in public" (Bauman, re:publica 2015). The result is, according to Bauman, a fear of being an unimportant person, the fear of exclusion. The IPC links this to the psychological aspects of precarity: "[T] he system holds the threat of forcibly delinking anyone any time. The present dominant affect of anxiety is also known as precarity. Precarity is a type of insecurity which treats people as 
disposable so as to impose control" (IPC 2014: 4-5). Cultural theorist Angela McRobbie shows, in her case-study of designers in Berlin and London, that gender, race, and class are often overlooked in the transformations that happen in the urban world of work:

$[T]$ he raft of equality measures of the type we associate with mainstream normal employment is often suspended if not reversed in this cruel (if also seemingly 'cool') environment where the US 'start-up' mentality prevails (...). Here we can see how the governmentality aspect of anticipated pleasure or promise of workplace sociability functions to close down awkward issues around race or sex discrimination (2016: 37-38).

In the realm of arts festivals and cultural events the competitive strategies of the market are prevailing. Innovative concepts are not applied to the festival structure itself but solely to the presented works of art. This means that there are no alternative approaches: Transmedia festivals likewise are ruled by the market, for example payment of artists and participants, workers or ticket distribution (4). The artists are paid in relation to their assumed market price, which results in huge fee-differences for performances at festivals. Another problematic aspect is that music and art are taken into service for the urban upgrading and gentrification processes. As stated above, these festivals rely mostly on existing art and music venues. Bigger festivals use more established (and thus secured) venues, but smaller scale festivals rely heavily on affordable small and medium-sized spaces. This is especially true for the music and art scenes outside of the festival realm; they are the breeding ground for the future artistic productions shown at these festivals, and those spaces appear less and less in the inner-city centres (Ludewig 2019). As stated by Yvonne Doderer, a transdisciplinary architect and activist who is professor for gender and cultural studies in Düsseldorf, Germany, art and culture are increasingly used for consumption and to aestheticize commercial activities (2013: 51). Events contribute, as content producers, to the (positive) branding of a city, and the number of Biennales, Triennales, and annual festivals of any format increase constantly. Meanwhile, the funding system is cultivating dependencies, as more and more events are applying and competing for the funds. Musicologist Alenka BarberKersova (2007) also underlines that the musical underground became not only accepted, but brings forward new economic ideas, such as co-working spaces, creative campuses, artist-residencies, and festivals. Festivals and events thus become a highly competitive field, especially in places like Berlin that attracts artists, cultural workers, and entrepreneurs from all over the world. The terms festivalization and eventization try to capture these processes.

According to Hitzler, events are condensed in space and time and create worlds of cultural experience with a strong appeal aimed at consumption. Events provide spaces of possibilities; they promise experiences and occasions for collective selfstaging (2011: 13-14). Eventization, as Hitzler puts it, is not stoppable. It is already as natural and prevailing as globalization or medialization. Entrepreneurs of all kinds have discovered the effectiveness of events as a marketing tool; and as a consequence, events are increasingly growing in size. Hitzler terms this as "accelerated eventization" (ibid.). And this is clearly not meant in a positive manner, because he compares it to a "Juggernaut", a force which destroys anything in its way (ibid.: 96).

For Holt and Wergin, the processes of festivalization play a key role in the relationship between music and the city: "During the 1980s and 1990s, city marketers, advertising agencies, policy makers, and cultural institutions started to 
recognize the communication potentials of cultural events. This development quickly became identified with the term festivalization" (Holt and Wergin 2013: 6; cf. Quinn 2005). Sociologist Andreas Reckwitz outlines in his book On the Invention of Creativity (2012) the strategies of culturalization: semiotization, reflexive historization and affective, sensual aestheticization of the urban environment (278). The first two aspects contribute to the aestheticization of the urban atmospheres, which is pushing forward the establishment of a dispositive of the creative city. Since the 1970s, this is an ongoing process where the inner city is upgraded with the musealization of historic landmarks, with postmodern spaces of consumption, and creative clusters. Ideas of subcultures or critical city planning were picked up by the governments and led to a more culturally orientated urban environment. The agents that today accelerate this process are the subcultures and art scenes, the academic middleclass, the enterprises of the creative economy and consumption, and the municipal politics (ibid.: 287). These agents are all connected to processes that overlap, interact, interlink, and gain momentum. Taking it to the bottom line: How cities are governed, controlled, and managed in late capitalism depends on cultural dynamics. Reckwitz calls this process, according to Foucault, the governmentality of urban culture and aesthetics. My research subjects refer to it as cultural gentrification.

Canadian communications scholar Geoff Stahl went twice to Berlin to research music scenes and, particularly, the CTM festival. After his first visit he wrote the article "Play on your own risk: Scenes of a 'Creative City'" (2005), where the title already reveals suspicions. However, he underscores the festival experience and many of its positive aspects. But upon his second visit several years later, he notices the manifestation of a cultural precariat in Berlin, and this becomes crucial for his view on CTM and Berlin scenes (2014):

\begin{abstract}
The cohort of creative individuals is caught up in the tenuous, but increasingly central, cultural economy (...) The precarious nature of creative life in a socalled 'new' urban context is one where entrepreneurship, creativity, innovation and cultural labour are activities shaped by an ideology that values flexibility, mobility, immediacy, efficiency and adaptability. For many artists (and countless others) living and working in New Berlin (and other cities), there are no guarantees, no assurances of a sustainable career, (...) in a creative field which privileges uncertainty as the necessary force driving its competitiveness (2014: 193).
\end{abstract}

The city itself becomes a commodity that is on sale, while art and music are a more distinctive form of consumption; at least for those who benefit from the neoliberal politics and are able to afford it (Doderer 2013: 50). For Doderer, conflicts are common in the history of cities, but the urban quality of life is also determined by who is successfully included. Regarding inclusion, Oktay's perspective on Berlin's music and art scenes is more disenchanting, as nothing is safe from being hijacked for consumption and, thus, there are no alternatives: "the rockstar's way of life has been appropriated by the techno DJ, the visual artist and the culturepreneur (...) so there actually is no need for activism; the creative lifestyle package already comes with the official stamp of dissidence" (2014: 220). He characterizes Berlin by a loss of gravity "this joyful vitality in the air (...) as one is wandering around the increasingly gentrified parts of the city" (ibid.: 219). Andrej Holm calls gentrification "a global urban strategy" (2013) which expresses itself in many diverse types of gentrification. He describes the present situation in Berlin as "mainstream gentrification" (2016), where the dynamic of gentrification has submerged beyond the inner city. This happened largely unnoticed by Berlin's 
creative class, who are slowly becoming aware of this, as affordable apartments, also for the middle class, grow scarce.

\section{Conclusion}

As we have seen, many complex, problematic, and ambivalent aspects connect events like festivals to cities as well as to economics, technologies, European policies, and local politics. In this scenario, culture is caught between state and market. Contemporary avant-garde festivals try to show critical cutting-edge art and create spaces of possibility, but they are themselves limited in their potential. The critique of curators or artists is soon hijacked and assimilated in the process of profitmaking by manufacturers of clothes, drinks, software, or service providers. Equal opportunities, an innovative form of organization, or fair pay is not on the agenda of most researched festivals. The festivals' organizers strive for innovation, transgression, future visions, and social or artistic experimentation, but rarely apply these ambitions to their own organizational structure or the networks and structures they are part of.

Even though my research is not focused on media art - although it investigates some of its artistic expressions, that appear together with musical works at these festivals - the history of media art is important, as media art is presented at most of these avant-garde festivals. This is due to funding opportunities of the past, an existing overlap within the scenes, and processes of cultural gentrification, which push distinctive tastes into the mainstream that were previously linked to specific communities with a DIY spirit (events where makers outnumber consumers). Companies and brands discovered these distinctive scenes and tastes increasingly as new market opportunities (interview Rohlf 2018). According to Voropai, the theme of the collaboration between art and science has developed in recent years into a new institutional paradigm, whose dynamics seem to repeat the culturalpolitical fate of media art itself. Since new media art is not new anymore but everyday experience, discourses and institutions now head towards Art-Science Collaboration and Artistic Research. Voropai points towards an increasing culturalpolitical instrumentalization within this new Art-Science paradigm that led to a whole new body of institutions and to new kinds of cultural hegemony within art practices and also science. Knowledge capitalism and the academization of art are further core issues, because universities and academia are increasingly part of and affected by this, and future research must also include the neoliberal university. Joint administration essentially shapes the whole of European cultural policy, as Voropai points out, ever since the term "cultural policy" was put into use. This leads to a feedback system, and art becomes a means for the popularization of science where artistic quality is increasingly valorized by quantitative measurements (2017: 309-310).

As a consequence, festivals which previously had a strong emphasis on music, like Future Everything in the UK (Ex-Future Sonic Festival, and formally member of ECAS network), or on media art, like Ars Electronica in Austria, have now become centre locations for Science-Art productions, as this secures their economic survival (cf. interview Future Everything 2015; interview Future Lab/ Ars Electronica 2014). Most of the transmedia festivals that still feature music as a core element have an uncertain future. Many of them, like CTM, have program features like laboratories (in case of CTM called "Hacklab") that are supposed to give an impression of scientific or technological value. In Berlin, where the attractiveness of techno and club culture for tourism has become evident for the government, there is hope that 
they can somehow retain or even increase their finances and thus successfully compete against brands and companies due to new funding possibilities by the Musicboard (since 2013), the City Tax funds (since 2014), or a newly established festival funding of the Senate Department for Culture and Europe (since 2018). For festivals in the post-socialist countries, the situation is much more difficult as there is hardly any funding for these kinds of events (cf. interview Rokolective 2015 \& 2017, cf. interview UH Fest 2017, cf. interview SHAPE 2018).

Questions of diversity - be it the equality of gender or equal opportunities of global art - are, as such, based on mainstreaming trends which can be considered the marketing of former niches picked up by funding bodies and governments or on voluntary self-monitoring by curators. Otherwise tendencies towards equal opportunities within avant-garde festivals might soon be out of fashion and revealed as former tokenisms. A major challenge seems to be that there are only few alternatives to the existing funding systems and forms of organization. One of the few examples of independence is the hacker congress C3, which has taken place in Germany since 1984, and been located in Leipzig since 2017. The C3 applies the urge towards innovation and utopian impulses also to its own organizational structure. In its clever and elaborated structure, logistics, and organization, the congress can be understood as a work of art in itself. This is only possible because everybody is encouraged to engage in the organization of the contents or infrastructure, every contributing participant is also asked to buy a ticket. Here, volunteering is also an essential part of the undertaking, but with the difference of independence from the influence of brands, companies, and state government funding bodies and to secure an affordable entrance fee for everybody. Unlike other festivals, events, or conferences, where only a few people are volunteering in opposition to paid speakers, artists or workers, most participants at the C3 pay and volunteer.

I am not suggesting that all festivals should be organized as DIY events. This would also suggest that this kind of work is not only badly paid, but limited to unpaid work. Likewise, it is necessary to build knowledge about organizational structures that are able to create independent events. This provides spaces that are urgently needed, where innovative experiments and knowledge exchange can happen, that enable new ideas and concepts that could help to transform events, festivals, and the cities where they happen into places of more fairness, equality, diversity, solidarity, and adventure. Truly universal spaces of possibility "where space is not limited or defined by capitalism but radically open ended" (Williams, CTM 2013: 21.33-21.48).

\section{Endnotes}

(1) The $\mathrm{C} 3$ is not a transmedia festival but a hacker congress organized by the Chaos Computer Club (CCC). It nonetheless includes elements and characteristics of the festivals at stake. It was added to the sample to exemplify alternatives to the structural and organizational problematic.

(2) This is changing right now for CTM, after 20 years, due to a new type of festival funding: the festivalfonds of the senate department for Culture and Europe in Berlin. CTM and other festivals (for example Atonal) have been granted this festival funding for a short-term period 2018-2019.

(3) An example is the prestigious event Wiener Festwochen 2017-2018. Here a huge line up with many global co-curators in discourse, performance and music was put in effect by 
Thomas Zierhofer-Kin and his curatorial team; visitors were told to let go of their privileges. After the first edition, there was a lot of bad press about the event and part of the curatorial team had to leave. After a less radical and demanding edition in 2018, Zierhofer-Kin and the rest of his team had to leave, even though he should have been in charge until 2020.

(4) The global ticketing market is in large pieces owned by Live-Nation (US) and Eventim (Europe). The ticketing enterprise Eventbrite is often commissioned as assumed to be a less problematic alternative. But all of those enterprises seem to be especially invasive, as the global market was overtaken in a short period of time.

\section{Acknowledgements}

I wish to thank Tristan Bath for proofreading and Fabian Holt for advice.

\section{References}

\section{Bibliography}

Alloway, L. 1966. Art and the Communications Network. Canadian Art 23 (1): 3536.

Barber-Kersovan, A. 2007. Creative Class, Creative Industries, Creative City. Ein musikpolitisches Paradigma. In D. Helms, T. Phleps Ed. Sound and the City. Populäre Musik im urbanen Kontext. Bielefeld: Transcript: 11-30.

Boltanski, L. and Chiapello, É. 2003. Der neue Geist des Kapitalismus. Konstanz: UVK Publishing.

Chen, K. 2009. Enabling Creative Chaos: The Organization Behind the Burning Man Event. Chicago: University of Chicago Press.

Doderer, Y. 2013. Räume des Politischen. Dimensionen des Städtischen. Münster: MV Publishing.

Enzensberger, H.M. 1962. Die Aporien der Avantgarde. MERKUR 16/171, May 1962: 401-424.

Falzon, M.-A. 2009. Multi-sited Ethnography. Theory, Praxis and Locality in Contemporary Research. Farnham/ Burlington: Ashgate Publishing.

Female:pressure FACTS 2017. Available from: https://femalepressure.files.wordpress.com/2017/09/facts2017survey_version1_1_by_femalepressure.pdf. Accessed: 11 October 2017.

Hardt, M. 1999. Affective Labour. Boundary 226 (2): 89-100.

Hitzler, R. 2011. Eventisierung. Drei Fallstudien zum marketingstrategischen

Massenspaß. Wiesbaden: VS Verlag.

Hoffmann, D. 2017. Der Zauber eines neuen Anfangs. TAZ, January 14th. http://www.taz.de/!5371546/. Accessed: 2 February 2019.

Holm, A. -

2013. Berlin's Gentrification Mainstream. In M. Bernt, M. / B. Grell / A. Holm

Ed. The Berlin Reader: A Compendium on Urban Change and Activism.

Bielefeld: transcript: 173-189.

Holm, A. 2016. Gentrification und das Ende der Berliner Mischung. In E. von

Einem Ed.: Wohnen. Wiesbaden: Springer Verlag: 191-231.

Holt, F. and Wergin, C., Ed. 2013. Musical performance and the Changing City. Post-industrial Contexts in Europe and the United States. New York/ London: Routledge.

Ludewig, B. - 
2018. Kulturelle Praktiken transmedialer Festivals als Überschreitungen. In S. Alisch, S. Binas-Preisendörfer and W. Jauk, Ed. Dan̈̈ber hinaus.... Populäre Musik und Überschreitung(en). Proceedings 2. IASPM D-A-CH-Konferenz Graz 2016. Oldenburg: BIS-Verlag: 115-134.

2019. Beschaffungsmaßnahmen für Investor*innen: Sollten wir lieber noch mehr Drogen nehmen? Zur Relevanz von Musik- und Kulturräumen für die Stadt. In: A. Beck and M.C. Rissinger Ed.. Die Akte Mo.e. Protokolle einer abgesagten Zukunft. Wien: Edition Monochrom: 68-81.

Quinn, B. 2005. Arts Festivals and the City. Urban Studies 42 (5): 927-943.

Manovich, L. 2009. The Practice of Everyday (Media) Life: From Mass

Consumption to Mass Cultural Production? Critical Inquiry 35 (2): 324.

Marcus, G. E. -

1995. Ethnography in/of the World System: The Emergence of Multi-Sited Ethnography. Annual Reviews Inc., 95-117.

2009. With J. Faubion (Ed.): Fieldwork is not what it used to be. Learning anthropology's method in a time of transition. New York: Cornell University Press.

2013. With Sabine Hess et al. (2013): New Ends for Ethnography. In: S. Hess, M. Schwertl and J. Moser Ed.. Europä isch-ethnologisch Forschen. Neue Methoden und Konzepte. Berlin: Reimer Verlag, 309-318.

McRobbie, A. 2016. Be Creative. Making a Living in the New Cultural Industries. Cambridge: Polity Press.

Oktay, E. 2014. The Unbearable Hipness of Being Light: Welcome to Europe's New Nightlife Capital. In G. Stahl Ed. Poor But Sexy. Reflections on Berlin Scenes. Bern: Peter Lang Publishing: 211-225.

Reckwitz, A. 2012. Die Erfindung der Kreativität. Zum Prozess gesellschaftlicher Ästhetisierung. Berlin: Suhrkamp.

Relyea, L. 2013. Your Everyday Art World. Cambridge: MIT Press.

Stahl, G. -

2005. Play at Your Own Risk: Scenes from a "Creative City". SPIEL (24): 309324.

2014. Getting by and Growing Older: Club Transmediale and Creative Life in New Berlin. In G. Stahl Ed. Poor But Sexy. Reflections on Berlin Scenes. Bern: Peter Lang Publishing: 191-210.

Teissl, V. -

2012. Macht Geld die Welt rund? Betrachtungen zum kuratorischen und ökonomischen Prinzip in der europäischen Kulturarbeit. In G. Wolfram Ed., Kulturmanagement und Europä ische Kulturarbeit. Bielefeld: Transcript: 155168.

2013. Kulturveranstaltung Festival. Formate, Entstehung und Potenziale.

Bielefeld: Transcript.

The Institute for Precarious Consciousness. 2014. We are all very anxious. We Are Plan C. https://www.weareplanc.org/blog/we-are-all-very-anxious/. Retrieved: 12 January 2018.

Vakianis, A. 2012. Kooperationen als wichtige Überlebensstrategie und zentrale Arbeitsstruktur für Festivals am Beispiel des "steirischen herbst". In G. Wolfram, Ed. Kulturmanagement und Europä ische Kulturarbeit. Bielefeld: Transcript: 155-168.

Voropai, L. 2017. Medienkunst als Nebenprodukt. Bielefeld: Transcript.

Wellman, B. and Rainie, L. 2012. Networked. The New Social Operating System.

Cambridge et al.: MIT Press. 
Welz, G. 2013. Die Pragmatik ethnografischer Temporalisierung. In: Hess et al.

Ed. Europä isch-ethnologisch Forschen. Berlin: Reimer, 39-54.

Wittel, A. 2001. Toward a Network Sociality. Theory, Culture and Society 18 (6): $51-77$.

Wulff, H. 2007. Dancing at the Crossroads. New York: Berghahn Books.

\section{Videography}

Re:publica Berlin (2015) Presentation Zygmunt Bauman: From Privacy to Publicity [Online video]. Available from: https://re-publica.com/de/session/privacypublicity-changing-mode-being-world. Accessed 3rd January 2017.

\section{Audio}

CTM festival 2013, audio recording: Panel Death of Rave UK. Input presentation by Alex Williams. Available from: https://soundcloud.com/ctm-festival/ctm13death-of-rave-1-uk Accessed: 12 March 2014.

CTM festival 2019 panel, audio recording: Alternative Festival Models with Roskilde and Boom. Available from: https://soundcloud.com/ctm-festival Accessed: 15 February 2019.

\section{Interviews}

Jan Rohlf, CTM director. 2018. Interviewed by author, via Phone.

Mihaela Vasile, Rokolectiv director. 2015/ 2017. Interviewed by author, Bukarest/ Berlin.

Nun András, UH Fest organizer/curator. 2017. Interviewed by author, Budapest.

Michal Brenner, SHAPE coordinator. 2018. Interviewed by author, via mail.

Tony Clark (name has been changed by author), Future Everything. 2015. Interviewed by author, via phone.

Christopher Lindinger, research \& innovation director FutureLab/Ars Electronica. 2014. Interviewed by author, Linz. 